\title{
MENINGKATKAN PARTISIPASI AKTIF MAHASISWA MELALUI LESSON STUDY PADA MATA KULIAH GEOMETRI RUANG
}

\author{
Reni Untarti*, Anggun Badu Kusuma \\ Pendidikan Matematika, Universitas Muhammadiyah Purwokerto, Jl. Raya \\ Dukuhwaluh, Purwokerto \\ *E-mail: reniuntarti@gmail.com
}

\begin{abstract}
This research aims to increase the active participation of students through lesson study courses in the geometry of space subject. This type of research is a qualitative descriptive study with the subject is the class A students of the fourth semester in academic year 2015/2016 who are in the geometry of spaces subject with the number of students are 35. The instruments used are observation sheets of the students' active participation and documentation in the form of photographs and videos. The research procedures based on the stages of the lesson study were 3 cycles in which each cycle consisting of the activity plan, do, and see. This study shows that the results of learning process with the lesson study designed by the model lecturer and the observer can increase the students' active participation, particularly on the subjects of geometry of space.
\end{abstract}

Keywords: active participation, lesson study, geometry of space.

Menurut UU No. 20 tahun 2003 disebutkan bahwa pendidikan adalah usaha sadar dan terencana untuk mewujudkan suasana belajar dan proses pembelajaran agar peserta didik secara aktif mengembangkan potensi dirinya untuk memiliki kekuatan spiritual keagamaan, pengendalian diri, kepribadian, kecerdasan, akhlak mulia, serta keterampilan yang diperlukan dirinya, masyarakat, bangsa, dan negara. Berdasarkan undang-undang tersebut dapat disimpulkan bahwa dalam pembelajaran, peserta didik harus terlibat aktif untuk mengembangkan kemampuannya, baik kemampuan yang bersifat afektif, kognitif, maupun psikomotorik. Lie (2008) menyebutkan bahwa belajar adalah suatu kegiatan yang dilakukan peserta didik, bukan sesuatu yang dilakukan terhadap peserta didik. Peserta didik tidak menerima pengetahuan secara pasif, akan tetapi secara aktif harus membangunannya sendiri. Jadi, pengembangan kemampuan peserta didik yang terus-menerus harus menempatkan peserta didik sebagai subyek yang aktif, bukan objek penerima.

Peserta didik yang terlibat aktif dalam pembelajaran, ia berusaha untuk mencari sesuatu, berusaha melakukan sesuatu, berusaha untuk mengeksplorasi pengetahuan mereka untuk mengumpulkan segala informasi yang dibutuhkan dalam menyelesaikan masalah yang dihadapi (Silberman, 2007). Dengan 
terlibat aktif dalam pembelajaran, peseta didik akan memperoleh pengalaman langsung dalam menyelesaikan masalah, tidak hanya mendengar, sehingga mereka akan memperoleh pembelajaran yang bermakna. Menurut Sivan, dkk (2000), mahasiswa yang terlibat aktif dalam pembelajaran mampu berkontribusi dalam pengembangan dirinya terkait dengan kemampuan berpikir kritis dan pemecahan masalah. Selanjutnya, Sivan, dkk (2000) menambahkan bahwa dengan berpartisipasi aktif, mahasiswa akan mendapatkan informasi baru sebagai bekal mengembangkan potensi dirinya.

Partisipasi aktif merupakan keterlibatan mental, emosi, dan fisik dalam memberikan inisiatif terhadap kegiatan-kegiatan yang dilancarkan oleh organisasi untuk mencapai tujuan organisasi tersebut (Suryosubroto, 2002). Dalam hal ini organisasi yang dimaksud adalah organisasi pembelajaran untuk mencapai tujuan pembelajaran yang optimal. Menurut Diedrich (Sardiman, 2006), partisipasi aktif dalam pembelajaran meliputi kegiatan: 1) visual activities (membaca, memperhatikan), 2) oral activities (bertanya, berpendapat, memberi saran, diskusi), 3) listening activities (mendengarkan diskusi, mendengarkan penjelasan), 4) writing activities (menulis, mengerjakan tugas), 5) drawing activities (menggambar, membuat perta, diagram), 6) motor activities (melakukan percobaan), 7) mental activities (mengingat, mengambil keputusan), dan 8) emotional activities (minat, semangat, berani, percaya diri). Pada penelitian ini, partisipasi aktif meliputi kegiatan berikut. 1) Visual activities: kegiatan memperhatikan penjelasan dosen dan penjelasan teman saat presentasi. 2) Oral activities: kegiatan bertanya saat tidak memahami materi, diskusi, dan berpendapat. 3) Mental activities: kegiatan untuk menyelesaikan masalah yang diberikan oleh dosen, termasuk di dalamnya kegiatan menulis, menggambar, dan menggunakan media pembelajaran.

Walaupun partisipasi aktif sangat diperlukan dalam pembelajaran, akan tetapi pentingnya partisipasi aktif belum disadari sepenuhnya oleh peserta didik. Berdasarkan observasi yang dilakukan kepada mahasiswa semester IV tahun ajaran 2015/2016 pada mata kuliah geometri ruang diperoleh fakta bahwa: 1) saat pembelajaran, mahasiswa cenderung pasif, duduk, diam, dan tidak bersemangat dalam menerima materi pembelajaran dari dosen, 2) jika mahasiswa tidak memahami materi yang diberikan oleh dosen, mahasiswa tidak memiliki inisiatif untuk bertanya, baik kepada dosen, maupun kepada teman, 3) jika dosen memberikan kesempatan bertanya, hanya sedikit mahasiswa yang memanfaatkan kesempatan tersebut, 4) jika dosen meminta mahasiswa untuk mempresentasikan hasil pekerjaannya di depan kelas, tidak ada mahasiswa yang dengan inisiatif pribadi bersedia melakukannya, dan 5) saat berdiskusi, mahasiswa cenderung mendiskusikan hal lain, di luar pembelajaran.

Untuk mengatasi masalah di atas, berbagai upaya dapat dilakukan oleh dosen, salah satunya dengan meningkatkan kualitas pembelajaran, 
sehingga mahasiswa dapat meningkatkan partisipasi aktifnya saat mengikuti pembelajaran. Lesson study dapat menjadi alternatif yang dapat digunakan untuk meningkatkan kualitas pembelajaran. Baba (2007) menyebutkan bahwa lesson study merupakan suatu proses pembelajaran yang bertujuan untuk meningkatkan kemampuan guru/dosen dalam mengelola proses pembelajaran di kelas. Senada dengan Baba, Halvorsen dan Lund (2013) menyebutkan bahwa lesson study adalah suatu pembelajaran yang mengarahkan pengajar untuk meningkatkan kualitas dirinya, sehingga dapat meningkatkan kualitas pembelajaran. Dengan lesson study pengajar dapat menganalisis pelaksanaan pembelajaran, sehingga dapat meningkatkan kualitas pembelajaran dan membantu pengembangan profesionalitas para pengajar. Selain itu, membuka kesempatan bagi para pengajar untuk saling belajar berdasarkan praktikpraktik pembelajaran di kelas (Kemendiknas, 2012). Beberapa alasan yang mendasari pelaksanaan lesson study dapat digunakan untuk meningkatkan profesionalitas pengajar, meliputi: 1) pelaksanaan lesson study berdasarkan pengetahuan profesional yang berlandaskan praktik dan hasil pembelajaran, 2) lesson study menekankan pada kualitas belajar peserta didik, 3) tujuan pembelajaran menjadi fokus utama, 4) lesson study digunakan sebagai landasan pengembangan pembelajaran, dan 5) lesson study menempatkan pengajar sebagai peneliti pembelajaran (Syamsuri \& Ibrohim, 2009).
Geometri ruang merupakan salah satu mata kuliah wajib yang harus ditempuh oleh mahasiswa pendidikan matematika. Tujuan dari mata kuliah ini yaitu agar mahasiswa dapat menguasai bentuk geometri dalam dimensi tiga. Kompetensi yang harus dikuasai diantaranya adalah kemampuan untuk menggambar bangun ruang, kemampuan menggambar bidang iris bangun ruang, dan kemampuan menentukan luasan dari bidang iris tersebut. Untuk menguasai mata kuliah ini diperlukan partisipasi aktif dalam pembelajaran, tidak sekedar mendengarkan penjelasan dosen. Mahasiswa harus banyak berdikusi, bertanya, menulis, berlatih, berpendapat agar pemahaman tentang isi mata kuliah ini dapat tercapai dengan optimal. Jika mahasiswa hanya menunggu materi yang diberikan oleh dosen, mahasiswa akan menemui banyak kesulitan dalam menyelesaikan masalah yang ditemui. Oleh karena itu, berdasarkan uraian di atas, peneliti bermaksud meningkatkan partisipasi aktif mahasiswa dalam mata kuliah geometri ruang dengan pembelajaran berbasis lesson study.

\section{METODE}

Jenis penelitian yang digunakan adalah penelitian deskriptif kulaitatif dengan subyeknya adalah mahasiswa semester IV kelas A tahun ajaran 2015/2016 yang mengikuti kuliah geometri ruang dengan jumlah keseluruhan mahasiswa 35 orang. Instrumen yang digunakan adalah lembar observasi partisipasi aktif mahasiswa dan dokumentasi baik berupa foto ataupun video. Prosedur penelitiannya sesuai dengan tahaptahap pada lesson study selama 3 
siklus, yang mana setiap siklus terdiri dari kegiatan berikut.

1. Plan, pada tahap ini dosen model dan dosen observer menganalisis masalah yang harus segera diatasi dalam pembelajaran. Berdasarkan hasil diskusi disimpulkan bahwa masalah tersebut adalah partisipasi aktif mahasiswa yang belum maksimal dalam pembelajaran geometri ruang. Setelah itu, didiskusikan pembelajaran dan perangakat yang akan dilaksanakan dalam tahap $d o$.

2. Do, pada tahap ini diimplementasiakan apa yang telah direncanakan pada tahap plan. Dalam tahap do, salah satu dosen memimpin jalannya pembelajaran yang biasa disebut dengan dosen model, dan dosen lain bertugas mengamati jalannya pembelajaran. Fokus pengamatan bukan pada penampilan dosen model, melainkan lebih fokus pada aktivitas mahasiswa, dalam penelitian ini adalah partisipasi aktif mahasiswa. Proses pengamatan tidak diperkenankan mengganggu jalannya pembelajaran.

3. See, tahap ini bertujuan untuk merefleksikan dan mengevaluasi jalannya pembelajaran. Pada tahap see, dosen model menyampaikan kembali proses pembelajaran yang sudah dilakukan, dilanjutkan oleh para observer menyampaikan temuan-temuan menarik dalam pembelajaran, khususnya yang berkaitan dengan partisipasi aktif mahasiswa. Hasil refleksi dan evaluasi akan digunakan sebagai perbaikan pada siklus berikutnya, guna peningkatan kualitas pembelajaran.

\section{HASIL DAN PEMBAHASAN}

Hasil dari penelitian ini disajikan berdasarkan indikator partisipasi aktif sebagai berikut.

\section{Visual activities}

Visual activities meliputi kegiatan memperhatikan penjelasan dosen model dan penjelasan teman saat presentasi. Untuk aktivitas mahasiswa yang terkait dengan visual activities, pada siklus 1 masih cukup banyak mahasiswa yang tidak memperhatikan dosen ketika memberikan penjelasan, terlihat pada Gambar 1. Mahasiswa tersebut lebih sibuk bermain dengan plastisin, daripada memperhatikan penjelasan yang diberikan oleh dosen model. Pada pembelajaran geometri ruang ini, dosen model meminta mahasiswa membawa plastisin sebagai media yang akan membantu dalam pembelajaran terkait dengan menggambar bidang iris. Berdasarkan hasil pengamatan ada 7 orang mahasiswa yang tidak memperhatikan penjelasan dosen. Inisial mahasiswa tersebut adalah TG, MA, IS, HZ, NF, NT, dan RP. Sementara itu, pada Gambar 2 menunjukkan bahwa mahasiswa tidak memperhatikan penjelasan dari teman lain saat mempresentasikan pekerjaannya di depan kelas. Mereka lebih membahas masalah lain yang tidak ada kaitannya dengan pembelajaran atau memainkan plastisin. Berdasarkan hasil pengamatan, mahasiswa tersebut adalah TG, MA, dan IS. 

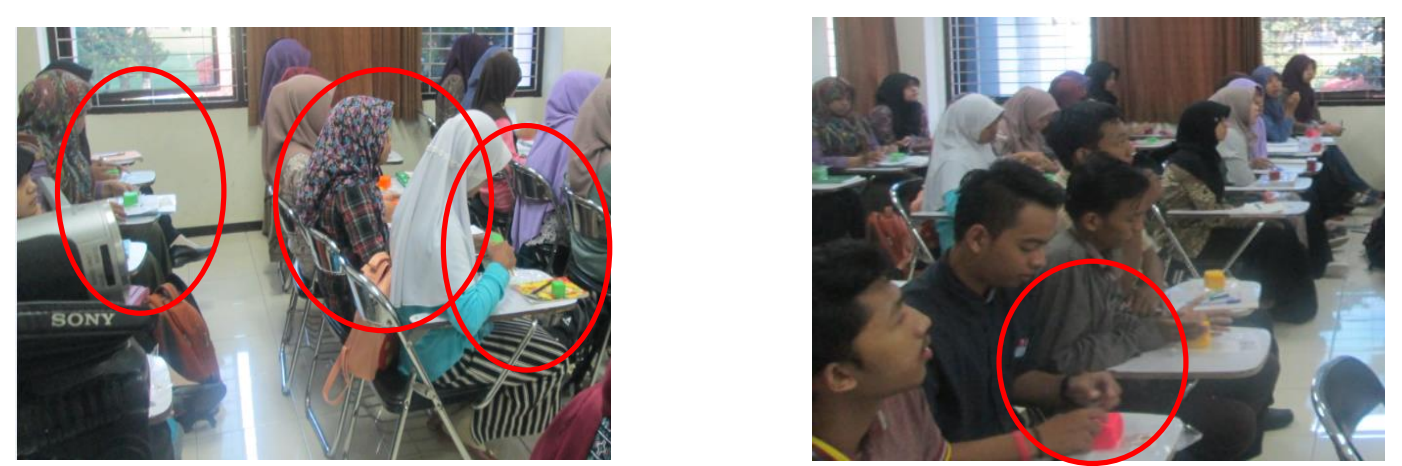

Gambar 1. Mahasiswa tidak memperhatikan penjelasan dosen pada siklus 1.
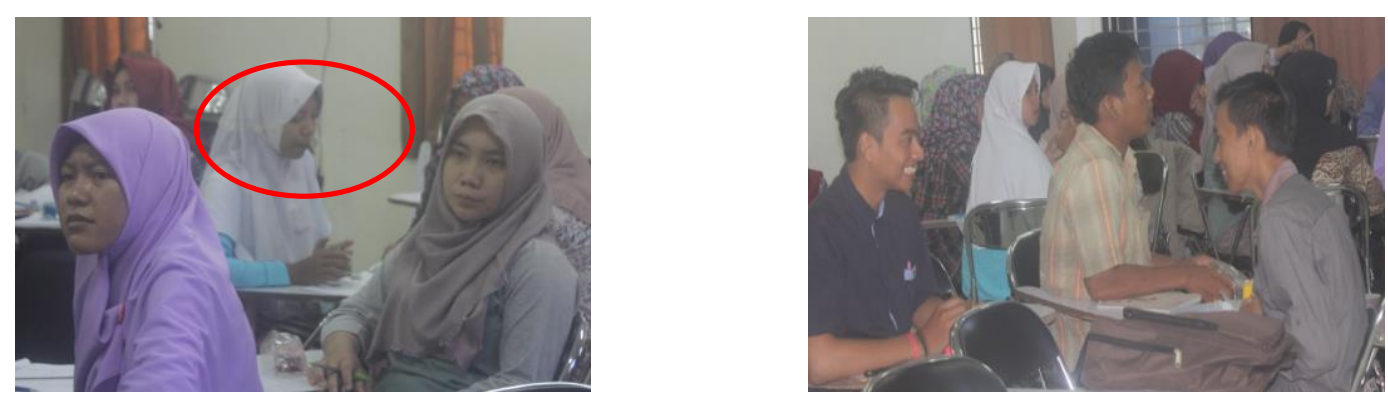

Gambar 2. Mahasiswa tidak memperhatikan penjelasan mahasiswa lain pada siklus 1.

Berdasarkan fakta di atas, dosen model dan dosen observer berdiskusi untuk mengatasi masalah tersebut dan hasilnya akan dilaksanakan dalam kegiatan do di siklus 2. Pada kegiatan do siklus 2 dosen model selalu mengingatkan kepada mahasiswa bahwa materi yang akan disampaikan adalah materi yang sangat penting, sehingga mahasiswa harus memperhatikan hal-hal yang disampaikan oleh dosen model. Selain itu, dosen model juga menunjuk mahasiswa yang tidak memperhatikan penjelasan untuk menjawab pertanyaan yang diajukan dosen model sesuai pembelajaran yang sedang dilakukan. Ketika ada perwakilan kelompok yang sedang presentasi, dosen model mengamati dengan seksama mahasiswa lain yang tidak presentasi. Kemudian, jika ada mahasiswa yang tidak memperhatikan, dosen akan meminta mahasiswa tersebut menjelaskan hasil diskusi kelompoknya di depan kelas. Usaha yang dilakukan oleh dosen model cukup mengatasi masalah tersebut. Hal ini terlihat pada Gambar 3, yang menunjukkan bahwa pada siklus 2 banyaknya mahasiswa yang tidak memperhatikan penjelasan dosen berkurang menjadi 3 orang, yaitu TG, DN dan ZA. TG dan DN sedang mengobrol, sedangkan ZA sedang memainkan plastisin. 

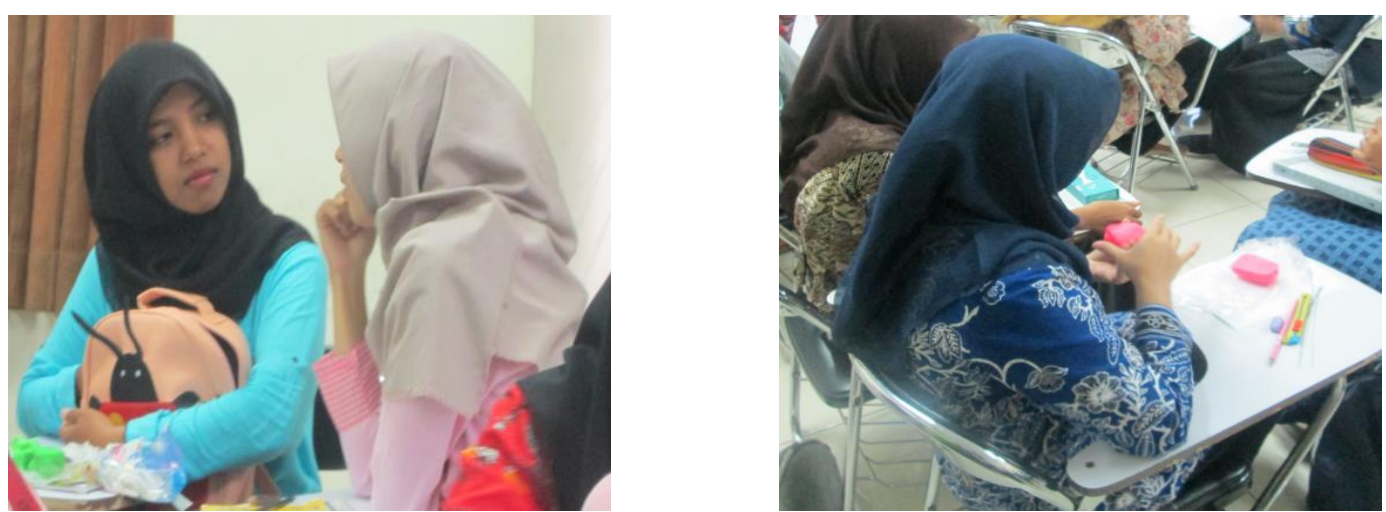

Gambar 3. Mahasiswa tidak memperhatikan penjelasan dosen pada siklus 1

Pada Gambar 4 menunjukkan bahwa TG kembali tidak memperhatikan ketika ada teman lain yang sedang mempresentasikan hasil diskusinya di depan kelas. Jika diamati, ternyata TG sedang sibuk dengan memainkan HP nya.

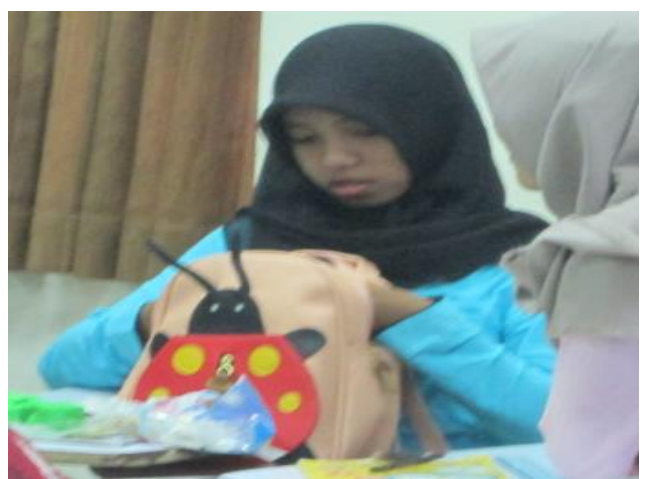

Gambar 4. Mahasiswa tidak memperhatikan penjelasan mahasiswa lain pada siklus 2 .

Pada Gambar 1, 2, 3, dan 4 terlihat baik di siklus 1 maupun siklus 2 mahasiswa TG kurang bertisipasi aktif dalam pembelajaran, khususnya bagian visual activitites. Berdasarkan fakta ini, pada kegiatan see siklus 2 dan plan siklus 3, dosen model dan dan observer memutuskan untuk lebih memperhatikan TG selama pembelajaran. Misalnya, dosen model akan langsung menegur TG jika selama pembelajaran di siklus ke 3 , ia kembali tidak memperhatikan. Pada siklus 3, ternyata semua mahasiswa sudah berpartisipasi aktif dalam pembelajaran, khususnya pada aktivitas visual. Hal ini ditunjukkan dengan semua mahasiswa memperhatikan penjelasan yang diberikan oleh dosen model, seperti terlihat pada Gambar 5.

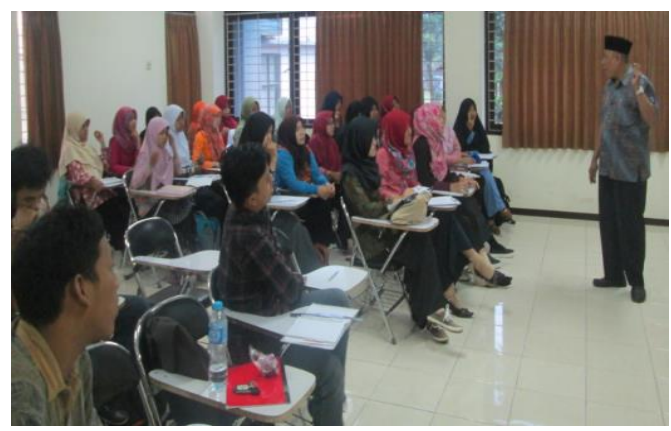

Gambar 5.Mahasiswa memperhatikan dosen model pada siklus 3 .

\section{Oral activities}

Oral activitites merupakan kegiatan yang menuntut mahasiswa untuk berpartisipasi aktif secara lisan, baik untuk bertanya, berdiskusi, dan berpendapat. Berdasarkan hasil observasi, diketahui bahwa pada siklus 1, ketika dosen memberikan kesempatan bertanya, tidak ada mahasiswa yang mengacungkan tangan untuk bertanya atau berpendapat dengan sukarela. Hal ini 
dapat dilihat pada Gambar 6. Pada proses penyelesaian tugas secara berkelompok, hanya dua kelompok yang bertanya kepada dosen saat

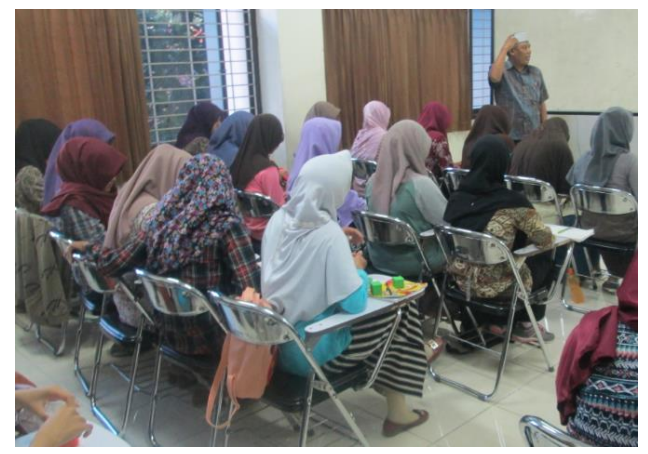

menemui kesulitan dalam menyelesaikan masalah, kelompok yang lain hanya pasif menunggu dosen mendatangi kelompok mereka.

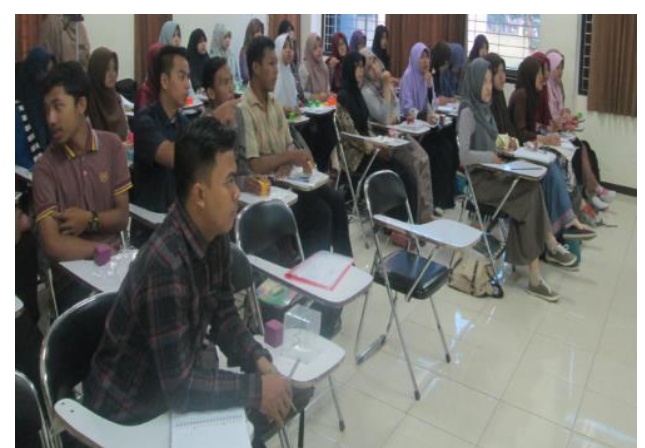

Gambar 6. Mahasiswa tidak ada yang bertanya ketika dosen model memberikan kesempatan bertanya.

Selain itu, pada proses diskusi juga ditemukan ada dua kelompok yang tidak berdiskusi secara optimal. Pada Gambar 7 terlihat bahwa ketika satu temannya sedang berusaha memecahkan masalah yang diberikan dosen, dua teman yang lain sibuk menggambar hal-hal yang tidak terkait dengan materi pembelajaran. Setelah dilakukan wawancara kepada dua mahasiswa tersebut, ternyata diketahui bahwa kedua mahasiswa tersebut merasa Lembar Kegiatan Mahasiswa (LKM) yang diberikan oleh dosen model hanya dikuasai oleh satu mahasiswa lainnya. Atau dengan kata lain, ada satu mahasiswa yang mendominasi proses penyelesaian masalah yang ada pada LKM saat berkerja secara berkelompok.

Gambar 8 menunjukkan bahwa ketiga mahasiswa dalam satu kelompok tersebut tidak berdiskusi mengenai masalah yang diberikan oleh dosen, melainkan membahas masalah yang lain yang tidak ada kaitannya dengan materi pembelajaran. Setelah dilakukan wawancara terhadap ketiga mahasiswa tersebut, diketahui bahwa ternyata mereka merasa sudah putus asa dan jenuh dalam menyelesaikan masalah yang diberikan oleh dosen, sehingga diskusi sudah tidak berjalan lagi. Akibatnya, mereka sibuk untuk mendiskusikan masalah yang lain. Hal ini menunjukkan bahwa mahasiswa tersebut tidak mempunyai inisiatif untuk bertanya kepada dosen, jika ada hal yang belum dimengerti.

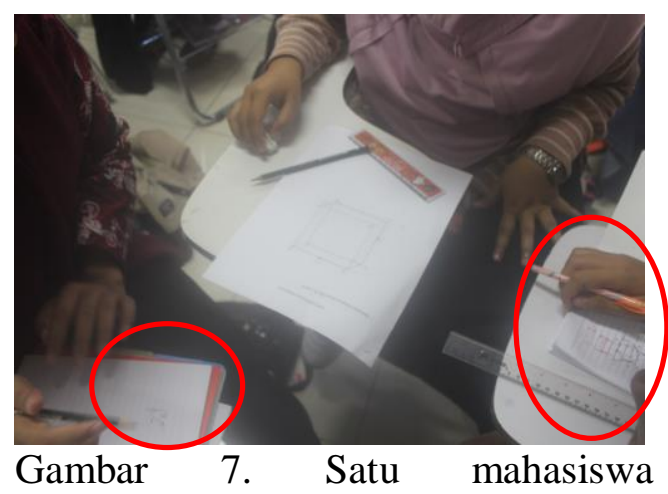
mendominasi LKM.

Berdasarkan temuan pada siklus 1, maka dosen model dan dosen observer berdiskusi untuk mencari tahu penyebab timbulnya masalah tersebut. Dari hasil diskusi 
diketahui masalah tersebut disebabkan karena banyaknya LKM yang diberikan oleh dosen model masing-masing satu untuk tiap kelompok. Untuk mengatasi hal ini disepakati bahwa pada siklus selanjutnya, masing-masing kelompok diberikan lembar LKM sebanyak anggota kelompok.

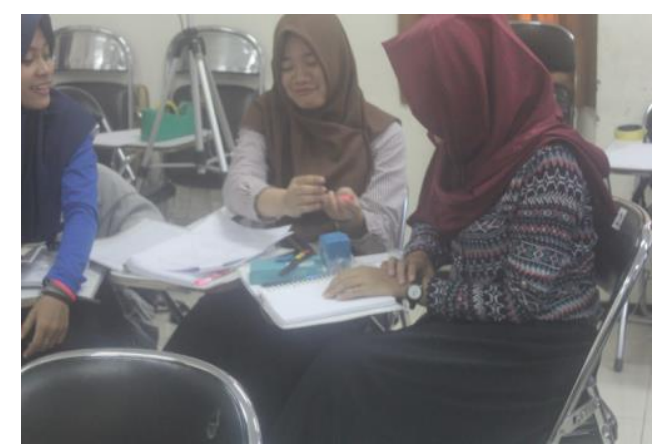

Gambar 8. Mahasiswa sedang mengobrol masalah di luar pembelajaran.

Harapannya, setiap anggota kelompok dapat memanfaatkan LKM, tidak ada salah satu mahasiswa yang mendominasi. Untuk mengatasi masalah yang kedua pada siklus 1, dosen model dan dosen observer sepakat untuk mengubah komposisi anggota kelompok. Dimana pada siklus 1 pembagian kelompok hanya berdasarkan tempat duduk terdekat, bukan kemampuan kognitif masingmasing anggota kelompok. Jadi, pada siklus 2, pembagian kelompoknya berdasarkan kemampuan kognitifnya. Dipilih 11 mahasiswa dengan kemampuan kognitif tertinggi (karena ada 11 kelompok), kemudian setiap 11 mahasiswa tersebut memilih dua atau tiga anggota kelompoknya yang lain. Harapannya, dengan adanya mahasiswa berkemampuan kognitif tinggi dapat menjadi motivasi bagi anggota yang lain, sehingga diskusi tetap berjalan.

Dengan diberikannya LKM sebanyak anggota kelompok, ternyata menimbulkan masalah baru, yaitu ditemukannya 1 kelompok yang tidak berdiskusi untuk menyelesaikan masalah yang diberikan oleh dosen, seperti terlihat pada Gambar 9. Mereka membagi tugas dalam menyelesaikan masalah tersebut. Misalnya, mahasiswa 1 menyelesaikan masalah nomor 1 , mahasiswa 2 nomor 2, dsb. Hal tersebut mengakibatkan tidak adanya diskusi dalam kelompok tersebut. Selain itu, hal ini mengakibatkan anggota kelompok tidak mempunyai pengalaman dalam menyelesaikan semua masalah yang diberikan oleh dosen. Mereka hanya mempunyai pengalaman menyelesaikan masalah sesuai dengan bagian atau tugas mereka.

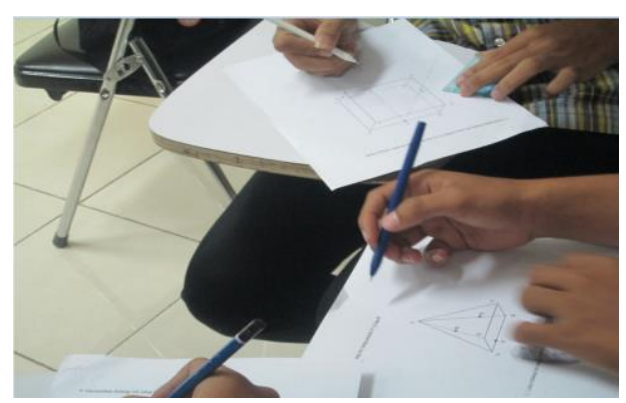

Gambar 9. Mahasiswa mengerjakan LKM sesuai bagian masing-masing.

Dengan membagi kelompok, di mana setiap kelompoknya terdapat 1 mahasiswa dengan kemampuan kognitif tinggi, ternyata cukup mengatasi masalah. Hal ini ditunjukkan sudah tidak ada lagi kelompok yang diskusinya macet atau merasa putus asa karena tidak dapat menyelesaikan masalah yang ada dalam LKM. Ketika mereka kesulitan 
dalam menyelesaikan masalah dalam LKM, mereka lebih berinisiatif untuk bertanya kepada dosen model atau kelompok lain yang memahami masalah tersebut. Ketika dosen memberi kesempatan untuk bertanya atau berpendapat, ada 1 mahasiswa yang berani mengutarakan pendapatnya kepada dosen model, seperti terlihat pada Gambar 10. Selain itu, mahasiswa dengan kemampuan kognitif tinggi dapat memotivasi anggota kelompoknya agar tetap berusaha jika ditemui kesulitan dalam menyelesaikan masalah. Salah satunya terlihat pada Gambar 11, di mana mahasiswa dengan kemampuan kognitif tinggi sendang menjelaskan proses penyelesaian masalah yang tidak dipahami kepada mahasiswa anggota kelompoknya.

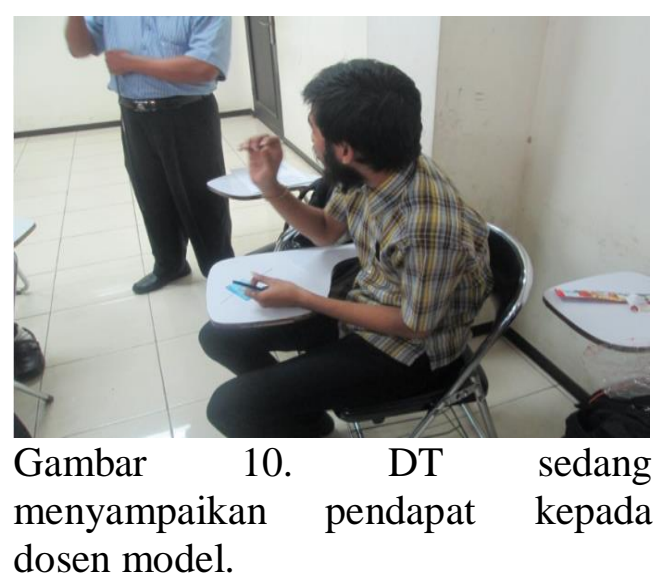

Untuk mengatasi masalah yang masih muncul pada siklus 2, tentang oral activities, khususnya tentang pelaksanaan diskusi, dosen model dan dosen observer sepakat bahwa pada siklus 3, LKM diberikan satu per satu setiap nomornya dan diberikan sebanyak anggota kelompoknya.

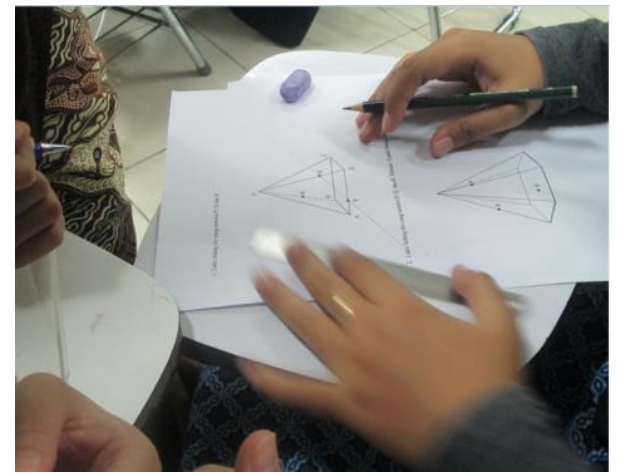

Gambar 11. Mahasiswa sedang menjelaskan kepada anggota kelompok.

Selain itu, dosen model memberikan waktu penyelesaian untuk setiap nomornya. Harapannya, walaupun setiap mahasiswa masing-masing berkeja, tetapi mereka mengerjakan permasalahan yang sama, sehingga jika ada mahasiswa yang kesulitan, mereka akan bertanya pada teman lain pada kelompoknya dan diskusipun akan berjalan.

Pada siklus 3, kegiatan yang terkait dengan oral activities semakin kondusif. Proses berdiskusi sudah berjalan dengan baik dan kondusif, seperti terlihat pada Gambar 12. Selain itu, pada siklus 3 lebih banyak mahasiswa yang berani mengajukkan pertanyaan jika tidak dimengerti di bandingkan pada siklus 2 maupun siklus 1. Hal ini terlihat pada Gambar 13 berikut. Ada 6 kelompok yang berani bertanya jika ada hal yang tidak dimengerti tanpa ditunjuk terlebih dahulu oleh dosen. Banyaknya mahasiswa yang berani mengutarakan pendapatnya juga bertambah dibandingkan siklus 1 dan 2. 


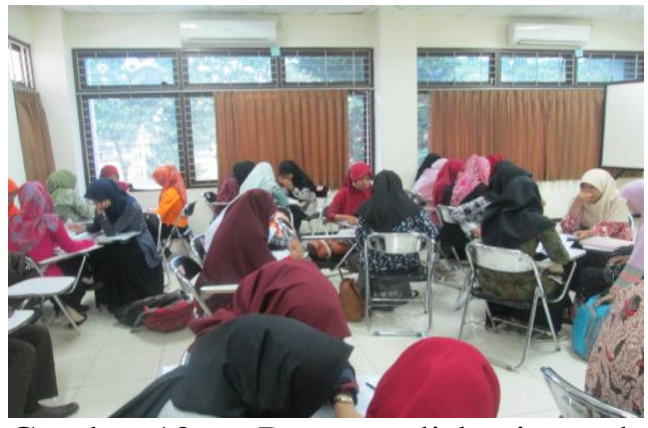

Gambar 12. Proses diskusi pada siklus 3 .

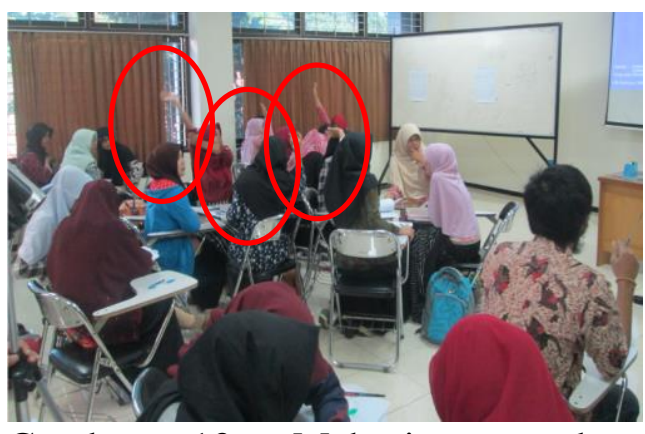

Gambar 13. Mahasiswa sedang mengacungkan tangan untuk bertanya kepada dosen model.

Pada siklus 3 ini ada 2 mahasiswa yang berani berpendapat kepada dosen tentang proses penyelesaian masalah yang diberikan oleh dosen, seperti terlihat pada Gambar 14.

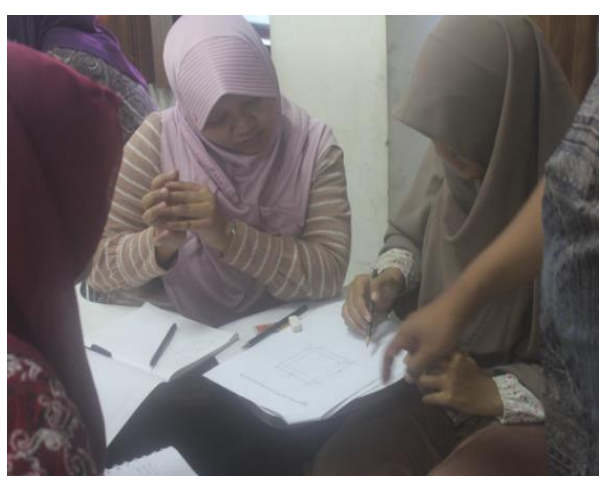

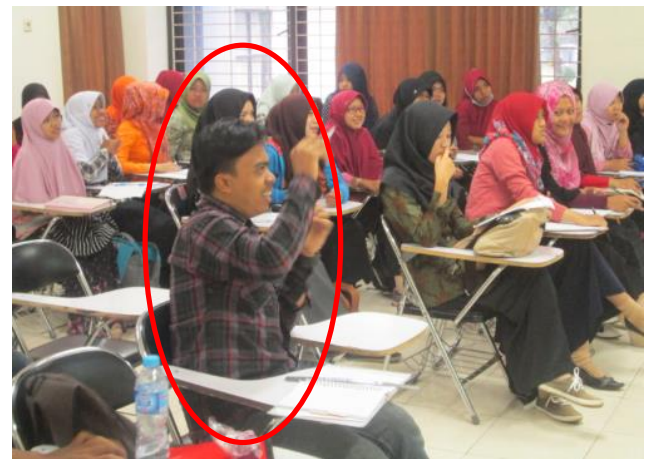

Gambar 14. Mahasiswa berpendapat pada siklus 3 .

\section{Mental activities.}

Mental activities, meliputi kegiatan untuk menyelesaikan masalah yang diberikan oleh dosen model, termasuk di dalamnya kegiatan menulis, menggambar, dan menggunakan media pembelajaran. Pada siklus 1, masalah yang harus diselesaikan adalah menggambar bidang iris pada kubus. Berdasarkan hasil observasi terlihat bahwa hanya satu kelompok yang dapat menyelsaikan masalah yang diberikan oleh dosen dengan benar. Kemudian, kelompok tersebut mempresentasikan proses penyelesaiannya di depan kelas. Kelompok yang dimaksud adalah kelompok EW, seperti terlihat pada Gambar 15.

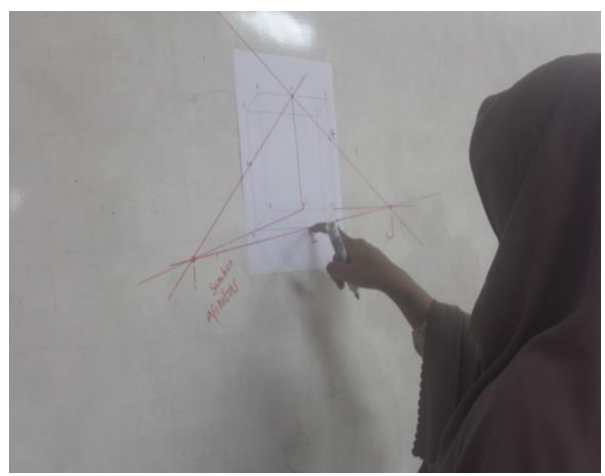

Gambar 15. Kelompok yang mampu menyelesaikan dan mempresentasikan proses menggambar bidang iris pada kubus. 
Selain itu, berdasarkan hasil observasi, pada siklus 1 seluruh kelompok tidak memberikan nomor urut pada langkah-langkah menggambar bidang iris seperti pada Gambar 16. Hal ini mengakibatkan mahasiswa kebingungan urutan langkah-langkah ketika diminta untuk menjelaskan kembali. Pada siklus 1, media pembelajaran yang berupa plastisin belum digunakan sebagai alat bantu pembelajaran. Kebanyakan mahasiswa menggunakan plastisin sebagai alat bermain seperti terlihat pada Gambar 1. Mahasiswa belum mempunyai inisiatif untuk memanfaatkan plastisin sebagai media pembelajaran. Mereka harus menunggu instruksi dosen model.

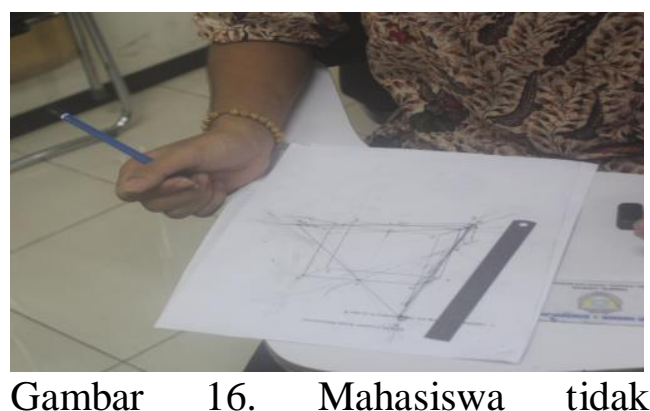
memberikan nomor urut pada langkah-langkah menggambar bidang iris.

Setelah dilakukan wawancara ternyata masalah yang timbul pada siklus 1 dikarenakan mahasiswa lupa tentang konsep titik, garis, dan bangun ruang, sehingga mereka kesulitan dalam menggambar bidang iris pada bangun ruang, khususnya kubus. Untuk mengatasi hal tersebut, berdasarkan hasil see siklus 1, diputuskan bahwa pada sebelum pembelajaran siklus 2 , dosen model mengingatkan kembali tentang konsep dasar titik, garis, sumbu afinitas, dan bangun ruang. Terkait dengan masalah tentang tidak dituliskannya langkah-langkah proses menggambar bidang iris, mahasiswa terlalu fokus pada hasil penyelesaian masalah, yaitu bentuk bidang singgungnya. Mereka melupakan bahwa memberikan nomor urut langkah-langkah menggambar bidang iris sama pentingnya dengan hasil bidang iris yang terbentuk. Untuk mengatasi hal tersebut, dosen model harus mengingatkan berkali-kali pentingnya memberikan nomor urut, agar mudah ketika mahasiswa diminta untuk menjelaskan kembali proses menggambar bidang iris yang telah diperoleh. Selain itu, dosen model juga harus sering mengintruksikan bahwa plastisin akan membantu mahasiswa untuk menyelesaikan masalah yang diberikan dosen.

Materi pembelajaran siklus 2 adalah menggambar bidang iris pada bangun ruang limas. Setelah dilaksanakan pembelajaran pada siklus 2, berdasarkan hasil observasi diperoleh bahwa ada peningkatkan banyaknya kelompok yang dapat menggambar bidang iris dengan tepat, yaitu 2 kelompok dari 1 kelompok di siklus 1. Kelompok yang dimaksud adalah kelompok yang dimotori oleh WD dan DT. Selain itu, kedua kelompok tersebut juga berani untuk berargumen tentang hasil Gambarnya terhadap dosen. Dua kelompok tersebut diminta maju ke depan kelas dan menjelaskan proses menggambar bidang iris yang mereka selesaikan seperti pada Gambar 17. Walaupun sudah ada peningkatan banyaknya kelompok yang dapat menggambar bidang iris dengan tepat, akan tetapi secara umum mahasiswa masih mengalami kesulitan. Penyebab kesulitan tersebut adalah kurang 
mantapnya pengetahuan mahasiswa tentang garis, titik, bangun ruang, dan sumbu afinitas yang menjadi prasyarat untuk menggambar bidang iris.

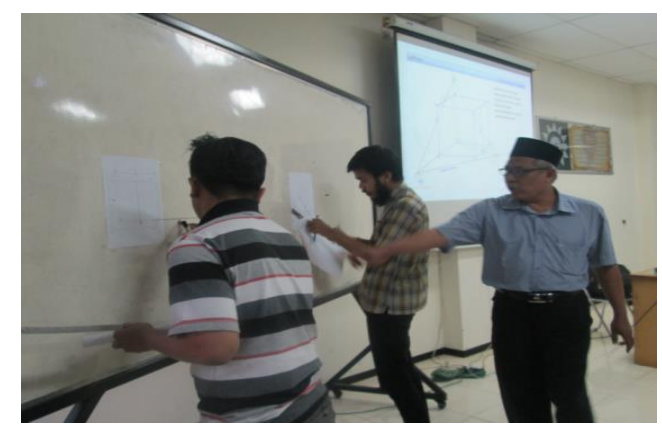

Gambar 17. Mahasiswa sedang mempresentasikan proses menggambar bidang iris di depan kelas.

Selain itu, seluruh kelompok sudah menuliskan langkah-langkah menggambar bidang iris, sehingga ketika diminta untuk menjelaskan kembali, mereka sudah tidak kebingungan. Akan tetapi, mahasiswa belum mampu menggunakan media secara optimal. Pada saat diingatkan, mahasiswa baru menggunakan media plastisin tersebut. Media plastisin yang akan digunakanpun belum siap, mahasiswa masih harus membentuk plastisin tersebut menjadi kubus, sehingga membutuhkan waktu yang lama.

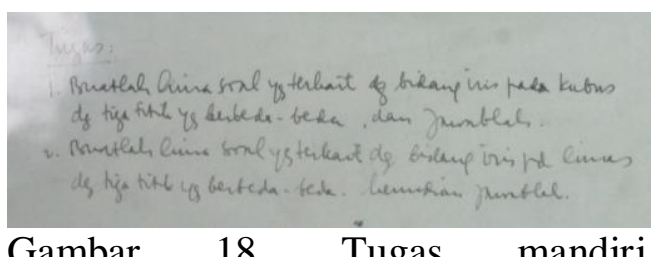
menggambar bidang iris.

Untuk mengatasi kesulitan tentang menggambar bidang iris yang terjadi pada siklus 2, dosen model memutuskan untuk memberikan soal tambahan sebagai tugas yang harus mahasiswa selesaikan di luar pembelajaran. Harapannya mahasiswa akan berlatih secara mandiri untuk menentukan bidang iris di bangun ruang. Soal tersebut terlihat pada Gambar 18.

Materi pembelajaran pada siklus 3 adalah menentukan luas bidang iris. Secara umum pada siklus ini, mahasiswa sudah mengalami peningkatan dalam kemampuan menggambar bidang iris, walaupun belum maksimal. Mereka sudah berkerja sama dengan baik dalam menyelesaikan masalah yang diberikan oleh dosen. Mereka juga sudah mempunyai inisiatif untuk bertanya jika ada hal yang tidak dimengerti. Akan tetapi, masalah lain muncul terutama terkait dengan menentukan luas bidang iris yang sudah terbentuk. Masalah tersebut masih terkait materi prasyarat yang kurang dikuasai oleh mahasiswa, yaitu materi perbandingan. Contohnya, Mahasiswa tidak bisa melukiskan jika data yang diketahui dalam bentuk perbandingan. Misalkan, mahasiswa tidak dapat melukiskan $A K: K B=2$, tetapi dapat melukiskan $A B: A K=3: 2$. Selain itu, mahasiswa mengalami kesulitan dalam merepresentasikan bentuk 3 dimensi ke dalam 2 dimensi. Hal ini terlihat ketika mahasiswa sudah menggambar bidang irisnya, mahasiswa kesulitan untuk menentukan bangun dari bidang iris yang terbentuk. Jika mahasiswa tidak mampu menentukan nama bangun datar dari bidang iris yang terbentuk, mahasiswa akan mengalami kesulitan dalam menentukan luasnya. Ringkasan kondisi mahasiswa dalam tiga siklus terdapat pada Tabel 1. 
Tabel 1. Ringkasan kondisi mahasiswa dalam tiga siklus.

\begin{tabular}{|c|c|c|c|}
\hline Indikator & Siklus 1 & Siklus 2 & Siklus 3 \\
\hline $\begin{array}{l}\text { 1. Visual } \\
\text { activities }\end{array}$ & $\begin{array}{l}\text { a. } 7 \text { mahasiswa yang } \\
\text { tidak } \\
\text { memperhatikan } \\
\text { penjelasan dosen, } \\
\text { sibuk memainkan } \\
\text { alat peraga } \\
\text { (plastisin). } \\
\text { b. } 3 \text { mahasiswa tidak } \\
\text { memperhatikan } \\
\text { penjelasan } \\
\text { mahasiswa lain } \\
\text { saat presentasi. }\end{array}$ & $\begin{array}{l}\text { a. } 3 \text { mahasiswa tidak } \\
\text { memperhatikan } \\
\text { penjelasan dosen } \\
\text { (berkurang } \\
\text { dibandingkan } \\
\text { siklus 1). } \\
\text { b. } 1 \text { mahasiswa tidak } \\
\text { memperhatikan } \\
\text { saat mahasiswa } \\
\text { lain menjelaskan } \\
\text { (mahasiswa yang } \\
\text { sama dengan } \\
\text { siklus 1, ia sibuk } \\
\text { bermain HP). }\end{array}$ & $\begin{array}{l}\text { Seluruh } \\
\text { mahasiswa } \\
\text { berpartisipasi aktif } \\
\text { ketika dosen } \\
\text { menjelaskan, } \\
\text { maupun } \\
\text { mahasiswa lain } \\
\text { sedang presentasi. }\end{array}$ \\
\hline $\begin{array}{l}\text { 2. Oral } \\
\text { activities }\end{array}$ & $\begin{array}{l}\text { a. Tidak ada } \\
\text { mahasiswa dengan } \\
\text { sukarela untuk } \\
\text { bertanya ketika } \\
\text { dosen } \\
\text { memberikan } \\
\text { kesempatan. } \\
\text { b. Saat bekerja } \\
\text { kelompok hanya } \\
\text { ada kelompok } \\
\text { yang berinisiatif } \\
\text { bertanya kepada } \\
\text { dosen, ketika } \\
\text { menemui } \\
\text { kesulitan, } \\
\text { kelompok yang } \\
\text { lain pasif } \\
\text { menunggu dosen } \\
\text { mendatangi } \\
\text { kelompok mereka. } \\
\text { c. Ada } 2 \text { kelompok } \\
\text { yang tidak } \\
\text { berdiskusi dengan } \\
\text { optimal, anggota } \\
\text { kelompok sibuk } \\
\text { menggambar hal } \\
\text { lain yang tidak } \\
\text { terkait dengan } \\
\text { materi. }\end{array}$ & $\begin{array}{l}\text { a. Ada } 1 \text { kelompok } \\
\text { yang tidak bekerja } \\
\text { sama saat } \\
\text { penyelesaian } \\
\text { masalah, mereka } \\
\text { membagi tugas } \\
\text { yang diberikan } \\
\text { dosen, sehingga } \\
\text { bekerja secara } \\
\text { individual. } \\
\text { b. Selain kelompok } \\
\text { pada bagian a), } \\
\text { seluruh kelompok } \\
\text { sudah bekerja } \\
\text { sama untuk } \\
\text { menyelesaikan } \\
\text { masalah yang } \\
\text { diberikan oleh } \\
\text { dosen. }\end{array}$ & $\begin{array}{l}\text { a. Seluruh } \\
\text { kelompok } \\
\text { sudah bekerja } \\
\text { sama untuk } \\
\text { menyelesaikan } \\
\text { masalah yang } \\
\text { diberikan oleh } \\
\text { dosen. } \\
\text { b. Banyaknya } \\
\text { kelompok yang } \\
\text { mempunyai } \\
\text { inisiatif untuk } \\
\text { bertanya jika } \\
\text { menghadapi } \\
\text { kesulitan } \\
\text { bertambah } \\
\text { menjadi } 6 \\
\text { kelompok. }\end{array}$ \\
\hline
\end{tabular}




\begin{tabular}{|c|c|c|c|}
\hline Indikator & Siklus 1 & Siklus 2 & Siklus 3 \\
\hline $\begin{array}{l}\text { 3. Mental } \\
\text { activities }\end{array}$ & $\begin{array}{l}\text { a. Hanya ada } 1 \\
\text { kelompok yang } \\
\text { mampu } \\
\text { menyelesaikan } \\
\text { masalah yang } \\
\text { diberikan oleh } \\
\text { dosen dan } \\
\text { mempresentasikan } \\
\text { nya secara } \\
\text { klasikal. } \\
\text { b. Seluruh kelompok } \\
\text { tidak memberikan } \\
\text { nomor urut pada } \\
\text { proses } \\
\text { penyelesaian } \\
\text { masalah, sehingga } \\
\text { menimbulkan } \\
\text { kebingungan saat } \\
\text { diminta } \\
\text { menjelaskan } \\
\text { kembali. } \\
\text { c. Mahasiswa tidak } \\
\text { memanfaatkan } \\
\text { plastisin sebagai } \\
\text { alat peraga dengan } \\
\text { baik, cenderung } \\
\text { untuk bermain- } \\
\text { main. }\end{array}$ & $\begin{array}{l}\text { a. Ada } 2 \text { kelompok } \\
\text { yang mampu } \\
\text { menyelesaikan } \\
\text { masalah dan } \\
\text { mempresentasikan } \\
\text { nya } \\
\text { b. Seluruh kelompok } \\
\text { sudah menuliskan } \\
\text { nomor urut } \\
\text { penyelesaian } \\
\text { masalah. }\end{array}$ & $\begin{array}{l}\text { Secara umum } \\
\text { mahasiswa sudah } \\
\text { mampu } \\
\text { menyelesaikan } \\
\text { masalah, akan } \\
\text { tetapi masalah } \\
\text { baru muncu, yaitu } \\
\text { terkait dengan } \\
\text { kemampuan } \\
\text { mahasiswa dalam } \\
\text { merepresentasikan } \\
\text { bangun ruang } 3 \\
\text { dimensi ke dalam } \\
2 \text { dimensi. }\end{array}$ \\
\hline
\end{tabular}

Dengan lesson study, dosen
meningkatkan kualitas pembelajaran, termasuk meningkatkan partisipasi aktif mahasiswa. Hal ini sejalan dengan hasil penelitian yang dilakukan oleh Murwaningsih dan Wulandari (2011) yang menyatakan bahwa lesson study merupakan salah satu cara efektif yang dapat digunakan oleh dosen untuk meningkatkan kualitas pembelajaran. Selain itu, Murwaningsih dan Wulandari (2011) menambahkan, dengan lesson study dapat digunakan untuk meningkatkan aktivitas mahasiswa dalam proses pembelajaran. Hal ini dikarenakan pada lesson study, dosen sudah merancang pembelajaran dengan baik berdasarkan masalah yang ditemukan dalam pembelajaran dan masukan dari dosen observer. Akibatnya, profesionalisme dan inovasi dosen dapat berkembang.

Sebelum pembelajaran, persiapan dilakukan antara dosen model dan dosen obsever. Dalam persiapan (plan) ini, terjadi focus group discussion untuk membahas masalah dominan yang muncul 
selama pembelajaran. Setelah itu, mendiskusikan juga solusi untuk mengatasi masalah tersebut yang kemudian akan dilaksanakan dalam pembelajaran $\quad(d o) . \quad$ Selama pembelajaran, dosen observer juga akan mengamati setiap aktivitas mahasiswa dan akan mencatat hal-hal yang menarik, khususnya terkait dengan masalah yang sudah didiskusikan sejak awal. Hasil-hasil temuan saat pembelajaran akan kembali didiskusikan antara dosen model dan dosen observer pada kegiatan see untuk dilihat kembali tingkat keberhasilan dalam mengatasi masalah yang muncul. Jika belum mengatasi masalah secara maksimal, akan direncanakan kembali solusi lain yang kemudian akan diterapkan pada pembelajaran siklus selanjutnya.

Fakta-fakta di atas mendukung teori yang disampaikan oleh Halvorsen dan Lund (2013) serta Baba (2007) yang menyebutkan bahwa tujuan dilaksanakan lesson study adalah untuk meningkatkan kemampuan dosen dalam mengelola pembelajaran. Akibatnya, secara tidak langsung dengan meningkatnya kemampuan dosen dalam mengelola pembelajaran diharapkan dapat meningkatkan kemampuan mahasiswa atau mengatasi masalah yang sedang dihadapi oleh mahasiswa yang terkait dengan pembelajaran. Dalam penelitian ini yang ingin ditingkatkan adalah partisipasi aktif mahasiswa saat mengikuti kuliah geometri ruang.

\section{SIMPULAN DAN SARAN}

Pembelajaran dengan lesson study yang telah dirancang oleh dosen model dan observer dapat meningkatkan partisipasi aktif mahasiswa, khususnya pada mata kuliah geometri ruang. Peningkatan tersebut dapat dilihat pada hasil dan pembahasan penelitian pada setiap siklusnya, di mana partisipasi aktif mahasiswa dilihat dari tiga aktivitas, yaitu visual activities, oral activities, dan mental aktivities. Untuk mental activities masih perlu ada tindak lanjut, agar hasilnya maksimal dan tujuan pembelajaran juga tercapai.

\section{DAFTAR PUSTAKA}

Baba, T. (2007). Japanese Education and Lesson Study: An Overview. Japanese Lesson Study in Mathematics: Its Impact, Diversity, and Potential for Educational Improvement. Singapore: World Scientific Publishing.

Halvorsen, A. L., \& Lund, A. K. (2013). Lesson Study and History Education. Retrieved Januari 24, 2016, from http://dx.doi.org/10.1080/00 377996.2012.698326.

Kemendiknas. (2012). Panduan Untuk Lesson Study Berbasis MGMP dan Lesson Study Berbasis Sekolah. Jakarta: IDC.

Lie, A. (2008). Cooperative Learning: Mempraktikkan Cooperative Learning di Ruang-ruang kelas. Jakarta: PT. Gramedia Widiasarana Indonesia.

Murwaningsih, U. \& Wulandari, A. A. (2011). Penerapan Lesson Study di Program Studi Pendidikan Matematika Fakultas Keguruan dan Ilmu 
Pendidikan Universitas Veteran Bangun Nusantara Sukoharjo. Seminar Hasil Penelitian dan Pengabdian Masyarakat. Sukoharjo: LPPM Universitas Veteran Bangun Nusantara

Sardiman. (2006). Interaksi dan Motivasi Belajar Mengajar. Jakarta: Raja Grafindo Persada.

Silberman, M. (2007). Active Learning: $101 \quad$ Strategi Pembelajaran Aktif. Yogyakarta: Insan Madani Islamic Publisher.
Sivan, A, dkk. (2000). An Implementation of Active Learning and its Effect on the Quality of Student Learning. Innovations in Education and Training International, Vol.37, No. 4, 381-389.

Suryosubroto, B. (2002). Proses Belajar Mengajar di Sekolah. Jakarta: PT Rineka Cipta.

Syamsuri, I., \& Ibrohim. (2009). Lesson Study. Malang: UM. 